\title{
Sonidos del poder y ruidos populares: el entorno sonoro de las fiestas regias en Valladolid de Michoacán
}

\author{
Sounds of Power and Popular Noises: Sound Environment \\ of Royal Festivals in Valladolid of Michoacán
}

JUANA MARTÍNEZ VILLA. Candidata a Doctora en Historia y profesora-investigadora de tiempo completo en la Universidad Michoacana de San Nicolás de Hidalgo, especialista en el estudio de la cultura y la política urbanas en México en los siglos XVIII, XIX y XX. Es autora entre otros trabajos del libro FIEsTa cívica y poder político en Morelia, 18911910 (UMSNH, 2017) y de "Lecturas bajo la piel de una ciudad. Consolidación urbana y cultural de Valladolid-Morelia, 1794-1898”, en J. M. Delgado Barrado, L. Pelizaeus, M. C. Torales Pacheco (eds.), LAS CIUdAdes EN LAS FASES TRANSITORIAS DEL MUNDO hispánico a los Estados nación: América y Europa (siglos XVI-XX), (Iberoamericana Vervuert, 2014).

MARCO ANTONIO LANDAVAZO. Doctor en Historia y profesor-investigador en la Universidad Michoacana de San Nicolás de Hidalgo. Entre sus últimas publicaciones destacan: "La reconquista, el príncipe y la isla: Gran Bretaña y el reconocimiento español de la independencia mexicana" en W. Fowler y M. Terrazas (coords.), Diplomacia, NEgocios Y POLÍtica. Ensayos sobre la relación entre México y el Reino Unido en el siglo XIX, (México, UNAM, 2018); y "El fantasma de la infidencia. Expresiones antimonárquicas en Nueva España en vísperas de la independencia”, en Tzintzun. Revista de Estudios Históricos, (62, jul-dic 2015).

RESUMEN. Entre los elementos que formaban parte de las ceremonias regias en Nueva España destaca uno al que, sin embargo, se le ha prestado poca atención: el entorno sonoro, formado por una serie de prácticas, como las voces del pregonero, el tañer de las campanas o la música popular y sacra. El objetivo de este trabajo es, así, describir y analizar, para el caso de Valladolid de Michoacán durante el reinado de los Borbones, el entorno sonoro de las celebraciones regias que era a la vez instrumento de las jerarquías políticas y sociales y espacio para la expresión popular.

PALABRAS CLAVE. Celebraciones regias, Entorno sonoro, Jerarquías políticas, Expresión popular, Valladolid de Michoacán

ABSTRACT. Sound environment -formed by a series of practices, such as the voices of the crier, the ringing of the bells, or popular and sacred music- was a very interesting part of royal ceremonies in New Spain, but It has been given little attention. The objective of this work is to describe and analyze, for the case of Valladolid de Michoacán during the reign of the Bourbons, the sound environment of the royal ceremonies, which was both instrument of political and social hierarchies and space for popular expression.

KEYWORDS. Royal ceremonies, Sound environment, Political hierarchies, Popular expression, Valladolid de Michoacán

INFORMACIÓN DEL ARTÍCULO

Recibido: 15 de febrero de 2017

Aprobado: 21 de junio de 2018

Correo para correspondencia: Marco Antonio Landavazo marcolandavazo@yahoo.com.mx 


\section{Sonidos del poder y ruidos populares: el entorno sonoro de las fiestas regias en Valladolid de Michoacán}

JUANA MARTÍNEZ VILLA, MARCO ANTONIO LANDAVAZO

Las fiestas regias en la América española constituyeron una extraordinaria manera de legitimar el poder de un monarca que nunca sería conocido físicamente en sus reinos de ultramar. La entronización de un nuevo rey, los nacimientos de infantes, el matrimonio de algún miembro directo de la familia real, las victorias militares que otorgaban gloria a la persona del monarca y hasta el embarazo de la reina o de alguna princesa, dieron lugar a ceremonias públicas con las que se buscaba exaltar las virtudes de la realeza al mismo tiempo que promover la fidelidad de los vasallos, mediante una serie de rituales y actos simbólicos que daban soporte y sentido a lo "maravilloso monárquico", para usar la feliz expresión de Marc Bloch.

Entre las prácticas y dispositivos que formaban parte del entramado de las fiestas regias en Nueva España es posible distinguir aquellos que, desplegándose en los espacios públicos más representativos de la ciudad, definían una auténtica cultura sonora de raíces criollas y mestizas: desde las altas voces del pregonero, el agudo tañer de las campanas que diariamente y a cada instante recordaban a los individuos el sentido mismo de su existencia o la música popular o sacra que pautaba el ritmo del tiempo festivo novohispano, hasta la algarabía de los asistentes a las diversiones públicas, el intercambio de las buenas y malas nuevas en las esquinas y plazas públicas y el bullicio de los comerciantes de a pie que ofrecían sus productos a los transeúntes.

Así, desde la fiesta real celebrada en honor de la coronación de Carlos V durante el siglo XVI hasta la sorpresiva y ajetreada jura de Fernando VII en vísperas del movimiento de independencia, la suntuosidad del ceremonial regio 
estuvo marcada por un entorno sonoro ${ }^{1}$ que era a la vez instrumento de las jerarquías políticas y sociales y espacio para la expresión popular. El objetivo de este trabajo es realizar en tal suerte una radiografía de las sonoridades de las fiestas regias para el caso de Valladolid de Michoacán durante el reinado de los Borbones; un acercamiento a esa serie de actividades donde lo lúdico y el ritual se hacían uno con el sonido de un sinnúmero de instrumentos, objetos y personas, y que formaron parte activa de la cultura vallisoletana, es decir, novohispana. Sonoridades que, visualizadas de esa forma, se vuelven una vía para acercarnos a las complejidades y contradicciones políticas y sociales que es dable observar a través del ceremonial público. ${ }^{2}$

La ciudad de Valladolid de Michoacán, capital de uno de los obispados más importante de la Nueva España, fue un ejemplo singular de una “episcópolis" novohispana, ${ }^{3}$ aunque tenía como referentes constantes en materia de fiesta y ritual a las ciudades de Puebla y México, como se precisaba en las ordenanzas emanadas de los cabildos civil y eclesiástico cuando se aproximaba alguna festividad regia. Pero además, a lo largo de la época colonial Valladolid disputó a la ciudad de Pátzcuaro el título de capital de la Provincia de Michoacán, un enfrentamiento que en el siglo XVIII se caracterizó por la utilización del ritual político, especialmente de la fiesta regia, como mecanismo legitimador a través del cual las oligarquías de ambas ciudades obsequiaban al monarca sus pleitesías, con miras al otorgamiento del título de capital; y en el contexto

1 Para la comprensión de la noción de entorno sonoro nos apoyamos en el concepto de paisaje sonoro desarrollado por Schafer (1994) y en la idea de ciudad como texto de Darnton (1987), de tal forma que nuestro concepto contempla los escenarios sonoros urbanos como prácticas culturales, y suma a lo auditivo lo visual, que para el caso de la fiesta regia es fundamental para comprender el significado del ritual político.

2 Son ya numerosos los estudios sobre las fiestas regias. Véase a manera de ejemplo: Varela (1990), Mínguez (1995), Mínguez y Rodríguez Moya (2006), Calvo (2003 pp. 23-41); Calvo (2005, pp. 67-92); Calvo (2011, pp. 73-103), Martínez Villa (2010), Mínguez, Rodríguez Moya, González Tornel y Chiva Beltrán (2012), Chiva Beltrán, (2012), Alberro (2012), Rodríguez Moya y Mínguez, (Dirs.) (2016).

3 Véase Rubial García (2017, pp. 217-266). 
de la fiesta regia, el paisaje sonoro cobró también una importancia política digna de considerar.

El siglo XVIII, la época de los Borbones, resulta por otra parte un periodo muy a propósito para pensar los códigos sonoros de la fiesta, pues es sabido que durante la segunda mitad de esa centuria las políticas encaminadas a la restricción de días festivos, al igual que de los barrocos repiques, dobles y redobles de las campanas, se verán puestos a prueba a partir de las medidas tomadas por las autoridades eclesiásticas y civiles. De tal forma que los entramados rituales se vieron trastocados durante las últimas décadas del siglo XVIII y la primera del XIX, cuando además los episodios convulsos de la metrópoli se trasladaron también a la ceremonia regia en Nueva España. Valladolid de Michoacán durante el siglo XVIII es pues un caso pertinente para explorar el entorno sonoro de las fiestas regias que distinguieron al mundo novohispano.

LOS SONIDOS DEL PODER

Entre el conjunto de ceremonias regias que se desplegaban en las ciudades de la monarquía española, la jura del rey era sin duda la más importante por razones evidentes: se trataba de la confirmación formal por parte de los súbditos de la legitimidad del monarca. La llegada de un nuevo rey al trono suponía por lo general el deceso del rey anterior, lo que producía una suerte de convergencia entre muerte y entronización regias que se revelaba tanto en la consabida fórmula “¡El rey ha muerto, viva el rey!” como en los documentos oficiales: apenas llegaba la Real Cédula al ayuntamiento donde se anunciaba la muerte del monarca español y pedía a los súbditos la organización de las exequias correspondientes, se iniciaban al mismo tiempo los preparativos para llevar a cabo la ceremonia de la real jura.

Los pregones mediante los cuales se daban a conocer a los habitantes de la ciudad las noticias del real fallecimiento y la orden de jurar al nuevo monarca constituían los primeros sonidos del poder de las ceremonias regias: eran el acercamiento inicial de la autoridad con la sociedad y el medio más importante para dar a conocer la información oficial. Por ello, y para que nadie alegase 
ignorancia, se buscaban los lugares más propicios para gritarlos que coincidían frecuentemente con los de las distintas celebraciones, tal y como ocurría precisamente en Valladolid de Michoacán. Se cumplía así la cédula emitida por Carlos II a fines del siglo XVII, en la que se establecieron las actividades y prohibiciones relacionadas con dichas ceremonias fúnebres. Al escuchar los pregones, la sociedad vallisoletana atendía el mandato oficial y se preparaba para iniciar en los siguientes ocho días los lutos correspondientes a las reales exequias. $^{4}$

El 2 de mayo de 1725, por ejemplo, los pregones que daban cuenta de la muerte de Luis I se iniciaron en los portales de las casas reales de donde partió una comitiva integrada por el alcalde mayor, el escribano del ayuntamiento y otros oficiales, "habiendo precedido son de clarines a la sordina y tambores enlutados por vos de Marcos de la Cruz indio ladino que hace oficio de pregonero". Las voces del indio se repitieron en la esquina de portales, del Hospital Real y de la casa de don Miguel de Peredo, recorrido que circundaba la catedral y la confirmaba en su carácter de eje urbano. Durante las exequias de Carlos III, los pregones estuvieron precedidos de la publicación de los bandos que informaban de la muerte del rey, efectuada por una comitiva formada por capitulares del ayuntamiento, gobernadores indios, integrantes de los tribunales de justicia y de la Acordada, que se hizo acompañar de la rítmica solemnidad de tamborileros y trompetistas. ${ }^{5}$

4 A pesar de su importancia, el oficio de pregonero llegó a denominarse un "vil ejercicio" y estaba mal remunerado, lo que ocasionó dejar a la ciudad sin los sonoros anuncios por largas temporadas. Archivo Histórico Municipal de Morelia (AHMM), Libro de Cabildo de la Ciudad de Valladolid, 1769-1772, no. 32, fs. 169-171. Hacia 1776, el cabildo ponderó la importancia del pregonero y se otorgó un salario de cuatro pesos mensuales. Real Cédula testimoniada para la jura del Señor Don Phelipe Quinto por muerte del señor Don Luis Primero, AHMM, Libros Manuscritos, No. 3, 1569-1755, fs. 155-155v. La cédula estipulaba, por ejemplo, seis meses de demostraciones y excepción otorgada a los indígenas, a quienes únicamente se les encargaba asistir a las oraciones y sufragios; igualmente, que los hombres vistiesen bayeta con corbatas negras y las mujeres lanilla con tocas y mantos delgados que no fuesen de seda.

5 AHMM, Libros manuscritos, no. 3, 1569-1765, fs. 155-160v; AHMM, Actas de Cabildo, Libro no. $63,1788-1789$, fs. 30-31v. 
Terminados los anuncios de la muerte del rey daban comienzo los lutos. Las reales cédulas recomendaban entonces silencio, semblantes afligidos y expresiones de dolor; los desconsuelos por el monarca duraban varias semanas, y al tiempo que se percibía la muerte suspendida los vallisoletanos sabían que el tiempo de la fiesta se acercaba. Después de los lutos, la ciudad celebraba la continuidad de la monarquía, el cuerpo político sempiterno del rey, por medio de la jura de su nuevo monarca. Aunque ésta se llevaba a cabo en un día específico, por lo general su organización incluía una serie de manifestaciones que duraban habitualmente tres días, marcados de inicio a fin por una diversidad de sonidos. Como los que producía el paseo del Real Pendón, que recorría los lugares principales de la ciudad, los lugares emblemáticos del poder político y religioso, rica y profusamente decorados previamente como ordenaba el bando correspondiente.

En Valladolid de Michoacán, como sucedía en otras ciudades novohispanas, la celebración de la fiesta regia delimitaba también un espacio neurálgico, caracterizado por la presencia de los poderes civil y eclesiástico, transfigurados en las Casas Reales, el Palacio Episcopal, la catedral, la plaza principal, la casa del alférez real y las calles centrales en las cuales se disponían conventos e instituciones notables como el de monjas dominicas y el Colegio de San Nicolás. Este espacio festivo que fungía además como una circunscripción política y sagrada en la medida en la que cada una de las etapas de la jura se llevaba a cabo. En este espacio dieron sentido a la fiesta regia la arquitectura efímera, el olor a pólvora, el gusto de refrescos, nieves, dulces, así como las ondas sonoras de las campanas, la gritería, la efusividad de cohetes y castillos, las notas de los instrumentos salidas de la capilla musical de la catedral, o bien de pífanos, tambores y clarines callejeros. ${ }^{6}$

6 Todo este despliegue festivo y sonoro fue aprovechado por Valladolid y Pátzcuaro en su pleito por adquirir la categoría de capital política de la Provincia de Michoacán, lo que se constata al revisar la documentación sobre las celebraciones reales en ambas ciudades. La disputa política se recrudecía desde que la cédula real, en que se informaba la muerte del monarca y se instaba a la preparación de la jura, llegaba a uno de los cabildos. Por lo general, durante el siglo XVIII, y sabiendo del pleito, los documentos referían que ambas ciudades organizaran las celebraciones por la coronación de un 
Durante la jura de Fernando VI verificada del 2 al 4 de diciembre de 1747, las casas vallisoletanas habían amanecido "entapizadas”, las calles limpias y las torres de las iglesias adornadas con banderitas y gallardetes, de conformidad con el bando publicado por el alguacil mayor Fausto Álvarez de Olate; pero destacaba la casa del regidor decano Luis Antonio Correa, quien había mandado poner en el balcón un dosel italiano de damasco carmesí, con el retrato del rey. ${ }^{7}$

Algo similar ocurrió durante la jura de Carlos IV, los días 11, 12 y 13 de febrero de 1791. El bando publicado por el intendente de la provincia Juan Antonio de Riaño ordenaba pintar las casas, asear las calles e iluminar los edificios, pero se "distinguieron mucho" las casas del ayuntamiento, la catedral, el palacio del obispo y la casa del alférez real, José Bernardo de Foncerrada, quien por cierto corrió con gran parte de los gastos de la ceremonia. Las primeras lucieron canalejas, fanales y hachas de cera, y un tablado con un dosel de terciopelo "galoneado de oro" en el que descansaban los retratos y una estatua del monarca. La segunda destacó por la iluminación de sus cornisas, torres y portadas. El tercero se vistió con un "lucido y costoso" cortinaje de terciopelo y una "elevada perspectiva de orden jónico" en la que se encendieron muchas candilejas. Y la última estaba "primorosamente pintada" y adornada con 3 mil 200 luces, numerosas hachas de cera en los balcones, colgaduras de damasco carmesí, cornucopias de cristal y un tablado con cuatro columnas y un frontispicio en el que habría de tener lugar el tercer acto de jura. ${ }^{8}$

nuevo monarca; sin embargo, el lucimiento en una u otra ciudad siempre constituyó un asunto de eminente rivalidad. Eso se observó por ejemplo durante la jura de Felipe V y Luis I, cuando las festividades principales se llevaron a cabo solamente en Pátzcuaro, ante el malestar profundo de los vallisoletanos. Al respecto véase Escobar Olmedo (1988, pp. 139-166). Los significados políticos y simbólicos de la disputa entre Valladolid y Pátzcuaro han sido abordados por Pulido Echeveste (2014).

7 La descripción de la jura de Fernando VI en Valladolid se encuentra reseñada en Rivera Cambas (1883, pp. 448-449). Información de interés sobre los gastos de dicha ceremonia en AHMM, I. 3.8.8, caja 43, exp. 29, 1747. Año de 1747.

8 AHMM, Gobierno, caja 48, exp. 10, año 1791, 8 fs, Valladolid, 12 de mayo de 1791 y Gazeta de México, tomo IV, núm. 32, martes 26 de abril de 1791, pp. 301-307. Este 
La ceremonia era solemne, pero era también ocasión tanto para la expresión de la alegría común que suponía la llegada de un nuevo soberano como para la demostración pública de la fortaleza local de la monarquía. El 2 de febrero de 1747 tocaron todo el día chirimías, trompetas, clarines, tambores y pífanos frente a la casa del regidor decano, quien se asomó al balcón a las 10 de la mañana, vestido de militar, y mostró el Real Estandarte que colocó sobre un cojín de terciopelo, dejándolo al cuidado de centinelas con alabardas. Por la noche se ordenó quemar fuegos artificiales frente a las casas reales, la del regidor decano, del palacio episcopal y en la plaza mayor, y en el resto de las casas se quemaron bombas y se dispararon cohetes, todo para la mayor gloria de Fernando VI. 44 años y 10 días después, el segundo día de la proclamación de Carlos IV, los integrantes del ayuntamiento salieron hacia la casa del alférez real, quien se sumó a la procesión con el Real Estandarte con ocho lacayos y los Reyes de Armas, los gobernadores de naturales, un piquete de dragones y a la retaguardia "un excelente golpe de música de instrumentos bélicos” y otro de la tropa, para regresar al ayuntamiento y encontrarse con el intendente Riaño para dar inicio ahí, en el tablado, el primer acto de la Real proclamación. ${ }^{9}$

El momento climático lo constituía propiamente la proclamación del monarca, que se verificaba en tres ocasiones durante el segundo día de festejos, en los tablados de las casas consistoriales, del palacio del obispo y de la casa del alférez real. ${ }^{10} \mathrm{El}$ tablado del ayuntamiento para la jura de Fernando VI era espacioso, con escalinata con barandales y un piso cubierto con alfombras en las que se dispusieron sillas bordadas de seda y un pedestal dorado para el Estandarte y un dosel para el real retrato. A las cuatro de la tarde, una vez que llegó la comitiva, el alférez Correa rindió frente al Pendón el juramento de

expediente ha sido publicado varias veces, pero el más completo, junto con otros documentos relativos, es el de Mejía Zavala (2003, pp. 163-224).

9 Rivera Cambas (1883, pp. 448-449); Gazeta de México, tomo IV, núm. 32, martes 26 de abril de 1791, pp. 303-304.

10 Durante el siglo XVII, cuando no se había construido aún el palacio episcopal, los tablados se montaban en espacios distintos. Durante la jura de Carlos II en 1666, por ejemplo, se instalaron frente a la casa de Jerónimo Magdaleno de Mendoza, teniente de alcalde mayor, y en las Casas Reales. Véase Martínez Villa (2010, pp. 101-103). 
pleito homenaje, protestando defenderlo con su vida. Enseguida, los Reyes de Armas dijeron en voz alta la fórmula de rigor -uno gritó tres veces "Silencio" y el otro tres veces "Oid”-, para que el alférez real, "en voz alta y acompasada", pronunciase acto seguido en tres ocasiones los nombres de Castilla, Nueva España y Valladolid de Michoacán, "por nuestro invicto Rey y Señor natural”. ${ }^{11}$

Las altas voces que aclamaban por su nombre al soberano y a la ciudad que le rendía homenaje constituían una verdadera apoteosis regia. A la voz del alférez la multitud respondía con vivas al rey, al mismo tiempo que se descorría el velo que cubría el retrato del monarca a lo que seguía una descarga de disparos y cohetes, el repique de las campanas de la catedral y las del resto de las iglesias. Los asistentes seguían con sus gritos y vivas, y entonces las autoridades les arrojaban monedas labradas para la ocasión, con la efigie del monarca y las armas de la ciudad. En las proclamaciones de Fernando VI y de Carlos IV, junto con las monedas fueron arrojados los recipientes que las contenían. Lo hizo el hijo del alférez Correa en 1747, quien arrojó un azafate de plata cincelada; y lo hizo también en 1791 el alférez Foncerrada, quien con mayor desplante tiró en tres ocasiones, además de las monedas de plata y cobre, la argentina fuente. $^{12}$

Terminado el tercer acto de la jura, daba inicio un último paseo para colocar en el tablado de las casas reales el Real Estandarte, que quedó resguardado por los centinelas y los reyes de armas en la jura de Fernando VI, mientras que en la proclamación de Carlos IV fue recibido por el intendente quien lo depositó en su pedestal. Y luego, una comitiva acompañaba al alférez real a su casa, y éste solía ofrecer un refresco, es decir, un agasajo de bebidas, dulces y alimentos. En febrero de 1791, José Bernardo de Foncerrada dispuso dos

11 AHMM, Libros manuscritos, núm. 22, 1742-1759, fs. 97-98; Rivera Cambas (1883, p. 449). Un resumen de las proclamas vallisoletanas del monarca español en Martínez Villa (2010, pp. 96-103 y 171-193).

12 El alférez Foncerrada pagó más de dos mil pesos por las 450 monedas de un medio real y de un peso, como testimonio, en sus palabras, de su lealtad al monarca. AHMM, Actas de Cabildo, Libro no. 69, 1790-1793, fs. 3, 18, 18v, 21v y 22. AHMM, Libros manuscritos, núm. 22, 1742-1759, fs. 97-98; Rivera Cambas (1883, p. 449). 
salones para lo que hubo que tirar varias paredes de su casa, en los que ofreció un "espléndido y lúcido" refresco al ayuntamiento y demás corporaciones en uno, y por la noche un baile en el otro, amenizado por una orquesta de instrumentos bélicos y de cuerda llegados de "lugares distantes". El alférez quiso así manifestar su lealtad y regocijo por los Soberanos. ${ }^{13}$

Las juras de Fernando VII tuvieron un significado especial, derivado desde luego de la situación de aguda crisis política que produjeron la invasión francesa de la península, las abdicaciones reales y el reinado espurio de José Bonaparte. ${ }^{14}$ De ahí el comentario del relator de la ceremonia que se llevó a cabo en Valladolid, en agosto de 1808: si los esfuerzos del amor, señaló, son siempre admirables, "nunca se conoció tan claramente su poder, como en la solemne proclamación de Fernando VII" celebrada en la capital michoacana. ${ }^{15}$ No era sólo retórica: se trataba en efecto de reconocer no a cualquier monarca, sino a uno cuyo cautiverio simbolizaba el peligro en que se encontraba la monarquía española.

Quizá por ello la sonoridad de la celebración fue particularmente ostensible en los días 24, 25 y 26 de agosto en los que el ayuntamiento de la ciudad acordó practicar la ceremonia. El segundo día se llevó a cabo el paseo que inició en la casa del alférez, encabezada por la nobleza citadina y los integrantes del cabildo civil, vestidos de gala y a caballo, "haciendo un espectáculo pomposo". Por delante marcharon los indios principales "con vestido español”, seguidos de los músicos en traje militar con instrumentos de viento y dos reyes de armas. Al frente de la comitiva que se dirigió a casa del intendente, el alférez real

13 AHMM, Gobierno, caja 48, exp. 10, año 1791, 8 fs, Valladolid, 12 de mayo de 1791; Gazeta de México, tomo IV, núm. 32, martes 26 de abril de 1791, pp. 301-307; Rivera Cambas (1883, p. 450).

14 Sobre la crisis política de la monarquía española de 1808 y su recepción en Nueva España véase Landavazo (2001, pp. 23-57). Entre una bibliografía ya extensa, pueden consultarse con bastante provecho las siguientes obras: Chust (2007), Ávila y Pérez Herrero (2008), Breña, (2010). Y el dossier titulado «1808: una coyuntura germinal» de Historia Mexicana (2008).

15 Relación descriptiva $(1808$, p. 1). Sobre el contexto político local de la proclamación, véase el estudio de Juárez Nieto (2008, pp. 33-53). 
portaba el Real Pendón. Al llegar a su destino, en el primer tablado, se escucharon los primeros vivas al rey junto a estallido de los truenos y el ruido de las monedas que se arrojaron a la multitud. ${ }^{16}$

Después de pasar por el segundo tablado en el palacio episcopal, el paseo desembocó en el tercero, en casa del alférez real, en donde continuó el ambiente festivo y tuvo lugar la proclamación última del rey "con las mismas demostraciones de la una y otra parte". Después de conducir la Reales Mazas a las casas consistoriales, el alférez ofreció un "refresco suntuoso y abundante a los caballeros y damas", durante el cual se pasearon las figuras de una máscara alegórica que había celebrado previamente a las armas españolas y se disfrutó de los músicos que también salieron a amenizar a la gente en las calles. Al final del día siguiente, una vez concluida la función religiosa y amainado la copiosa lluvia vespertina, el alférez ofreció un segundo refresco "tan magnífico y superabundante como el de la tarde antecedente". ${ }^{17}$

El mismo funcionario, "deseando obsequiar de algún modo a un pueblo que con tanto gusto había llenado su deber”, decidió ofrecer el día 28 una lujosa fiesta por la noche. Se dispuso para ello un par de salones, uno para el baile y otro para la cena, ambos decorados con suntuosidad: una parte de la tropa veterana para recibir a los invitados, hachas de cera que iluminaban las escaleras de acceso y varios candiles de cristal para los salones, asientos para señoras separados de los destinados para señores, cuatro espejos y un magnífico retrato de Fernando. Desde afuera podía escucharse el bullicio de una fiesta en la que alrededor de 200 personas de la elite comían, bebían, reían, departían y bailaban minuetes, contradanzas y boleras al compás de un "golpe de música completa capaz de excitar al más severo estoico a la diversión y alegría”. Al final la concurrencia cantó algunas piezas, declamó poemas y lanzó gritos de victoria. ${ }^{18}$

16 Relación descriptiva (1808, pp. 3-4).

17 Relación descriptiva (1808, pp. 4-6).

18 Relación descriptiva (1808, pp. 7-9). Las juras de Fernando VII provocaron un éxtasis sonoro en las ciudades novohispanas. Algunas de las composiciones musicales que formaron parte de ese paisaje fernandino han sido rescatadas por el proyecto MUSICAT, como se ve en el trabajo de Herrera (2006, pp. 24-38). 
MÚSICA, TAÑIDOS Y SERMONES

Parte fundamental de las ceremonias regias la constituían la función religiosa y, con ella, los sonidos propios que producía la participación eclesiástica en las celebraciones: música sacra, cantos religiosos, campanadas, procesiones, misas, rezos, discursos pronunciados en el púlpito. Para las reales exequias eran elegidos anticipadamente los canónigos encargados de la construcción efímera de la real pira, la oración fúnebre en latín y castellano y el sermón. En las celebradas en honor a Felipe V en 1747, la entrada del obispo hasta el presbiterio fue acompañada con el canto solemne de toda la capilla musical, “con arpa, violón y violines, escuchándose a dos coros la vigilia”. Entonces el obispo se disponía a subir a la pira, mientras que se cantaba a medio tono el salmo De Profundis y el Responso. El momento culminante de la ceremonia religiosa durante su primer día lo constituía la oración fúnebre exclamada desde el púlpito y cuyo responsable mantenía más o menos atenta a la comunidad de acuerdo con sus dotes de elocuencia. ${ }^{19}$

El segundo día de la ceremonia se veían llegar hasta los pies de la real pira las órdenes religiosas establecidas en la ciudad, las que bajo cruz, capas y ciriales se dedicaban a cantar misas y responsos. Curiosos e interesados leían y observaban los mensajes codificados en alegorías y versos plasmados en las distintas caras del monumento efímero, que contribuía didácticamente para fijar en el imaginario la figura de un monarca sempiterno. La representación regia quedaba también manifiesta en el sermón fúnebre que daba fin a la ceremonia religiosa, pieza oratoria que, a lo largo de la dominación española y no exenta de transformaciones, fue un vehículo de las principales ideas y doctrinas políticas que constituían la base ideológica de la monarquía hispánica. Aunque hay que decir que, en ocasiones, el sermón fue también instrumento para la promoción de los intereses de la ciudad, como queda de manifiesto en el publicado a instancias del canónigo Nicolás Joseph de Soria Villarroel y su

19 Archivo Histórico de la Catedral de Morelia (AHCM), Libros de actas de cabildo, no. 20, fs. 211-211v. 
hermano Jerónimo, marqués de Villahermosa y Alfaro, que fue parte de la defensa de Pátzcuaro como capital de provincia, en la década de los 30 del siglo XVIII. $^{20}$

En las ceremonias de proclamación del rey, la participación eclesiástica se verificaba desde el primer día, pero se volvía más notoria conforme avanzaban los festejos, para terminar coronando la ceremonia en el último día. Como hemos ya referido, la catedral, el palacio episcopal y el resto de las iglesias se adornaban al igual que el resto de los edificios públicos y privados. Después de la jura que tenía lugar en las casas reales, se llevaba a cabo un paseo que se dirigía hacia el tablado montado en el palacio del obispo, en el que se repetía el acto de la proclamación. Para la correspondiente a Carlos III, la comitiva -integrada por músicos indígenas y principales, soldados, el cabildo civil y vecinos "beneméritos" - fue recibida por el obispo Pedro Anselmo Sánchez de Tagle, su cabildo y el clero; y después de la jura se oyeron los vivas de la plebe, disparos de fusil y un "solemne general repique" de las iglesias de la ciudad, para terminar con el acto de arrojamiento de monedas a cargo del prelado. Lo mismo hizo el obispo Antonio de San Miguel, en la jura de Carlos IV en 1791.21

El tercero y último día por la mañana tenía lugar la función religiosa en la catedral. Integrantes del cabildo eclesiástico recibían en la entrada a los funcionarios municipales y los guiaban a los asientos designados, para dar inicio enseguida a la misa y al sermón, con la presencia del obispo. En la jura de Fernando VI, el cabildo civil, el Justicia y el Regimiento fueron recibidos por cuatro capitulares, y el sermón fue pronunciado por uno de los prebendados; en la de Carlos III fueron dos capitulares acompañados por los capellanes de coro quienes recibieron a los funcionarios y el sermón estuvo a cargo del rector del Colegio de la Compañía de Jesús; y en la de Carlos IV la recepción

20 Para una historia del sermón que comprende el periodo 1760-1834 y que analiza su tránsito de las formas barrocas, su paso por la predicación a la moderna alejada del sentido figurado y el alegorismo, hasta el talante romántico y cuasi secular del discurso cívico, véase Herrejón Peredo (2003). El sermón de los hermanos Soria Villarroel es: Rigor y Piedad de el rayo de la muerte (1727).

21 AHMM, Actas de Cabildo, Libro no. 28, fs. 29-30; AHMM, Gobierno, caja 48, exp. 10, año 1791, 8 fs, Valladolid, 12 de mayo de 1791. 
de la comitiva oficial fue enteramente similar y el sermón fue predicado por Ildefonso Gómez Limón, canónigo magistral de la catedral. ${ }^{22}$

Las sonoridades de índole eclesiástica que solían escucharse durante las festividades regias se muestran con meridiana claridad en la certificación de la participación del Deán y Cabildo de la Catedral de Valladolid de Michoacán en la proclamación de Carlos IV de 1791, que hizo el bachiller Rafael de Crespo, quien era el secretario del capítulo catedralicio, además de notario de la Inquisición. Por ese testimonio sabemos que el viernes 11 de febrero hubo tres misas, plegarias y repiques de campanas de una hora al mediodía y en la noche. El día 12 hubo coro a las dos de la tarde "por motivo de ser oficio de dominica", y en la noche fuegos artificiales afuera de la catedral, compuestos "de un castillo grande de veinte y cinco tiempos, con cuatro árboles en su círculo", además de tamboretes y otras piezas "muy vistosas" costeadas por la fábrica catedralicia. El domingo 13 se entró a coro a las siete de la mañana, y después de haberse rezado prima y tercia se cantó la misa conventual de la dominica; después de las ocho y media se comenzó a cantar la sexta con toda solemnidad como de primera clase, y finalizada se rezó nona en cuyo intermedio se recibió a la comitiva presidida por el alférez real; se entonó luego el Te Deum Laudamus y posteriormente se cantó la oración pro gratiarum actione.

Después tomando su señoría ilustrísima su asiento se comenzó la misa, que fue votiva de Sma. Trinitate, la que se cantó por el señor arcediano doctor Juan Antonio Tapia a quien tocó por turno con toda la solemnidad que fue posible, agregándose a los instrumentos y voces de la capilla de esta santa iglesia, los que se mandaron traer de Querétaro, siendo por tanto esta función la más solemne que se ha ejecutado con seis cetros y todo lo demás de primera clase. Concluido el evangelio, predicó el señor magistral doctor don Ildefonso Gómez el sermón que de antemano se le había encomendado. Finalizada la misa que duró hasta las doce del día, se depositó al Santísimo por su señoría ilustrísima en la forma

22 Rivera Cambas (1883, pp. 450-451). AHMM, Actas de Cabildo, Libro no. 28, fs. 29-30; AHMM, Gobierno, caja 48, exp. 10, año 1791, 8 fs, Valladolid, 12 de mayo de 1791. 
acostumbrada, y habiendo dejado los pontificales, tomó su capa magna, y le salieron a dejar los señores capitulares, y ministros que son de estilo; y luego a la nobilísima ciudad los dos señores canónigos, y cuatro padres capellanes, señalados por el señor deán. Dadas las ocho de la noche de este día, se comenzaron a voltear las esquilas hasta las ocho y media, que comenzó otro solemne repique, a que acompañaron en las demás iglesias, como se previno en el ceremonial y finalizó a las nueve. Con lo que concluyó esta santa iglesia su función. ${ }^{23}$

La capilla musical de la catedral vallisoletana constituyó un importante repositorio de la tradición michoacana formada en espacios predominantemente agustinos desde el siglo XVI. La fabricación de instrumentos musicales, el conocimiento y la práctica de la música y el canto dieron pie a la apertura de una "escoleta", y posteriormente de la casa de Infantes donde se instruía a los futuros capellanes y músicos de capilla. De manera permanente, la capilla musical michoacana se vio enriquecida con el intercambio de maestros y músicos, venidos principalmente de Puebla, Ciudad de México y Querétaro; algunos de ellos por estancias cortas, y otros para radicar definitivamente en la ciudad. $^{24}$

Además del interior catedralicio, hubo escenarios eclesiásticos importantes para la jura en espacios abiertos. Para las celebraciones a Fernando VII ya referida, se dispuso un tablado afuera del palacio episcopal, en donde habría de recibirse a la comitiva encabezada por el alférez real. El tablado había sido decorado con versos castellanos de temas latinos que anunciaban "el propósito de la oración que había de pronunciarse al día siguiente”. Sobre el mismo esperaba el Cabildo, que al llegar la procesión manifestó su júbilo a través de su presidente y de algunos prelados, que derramaron una cantidad considerable

23 El bachiller don Rafael de Crespo, presbítero, notario del Santo Oficio de la Inquisición de este reino, y secretario del Muy Ilustre y Venerable Deán y Cabildo de esta Santa Iglesia Catedral de Valladolid de Michoacán, AHCM, Actas de Cabildo, libro 37, 17891792, fs. 161, 167, 167v, 169v, 172v, 173-175, 176v. Véase al respecto Martínez Villa (2010, pp. 95-97) y Mejía Zavala (2003, pp. 179-180).

24 Mazín (2006, pp. 205-218). 
de dinero, en medio de vivas y aclamaciones. Frente a la catedral, por su parte, se habían colocado un "fuego de invención" y en sus cuatro costados imágenes de Jesús, del rey, de las armas pontificales y de las armas reales, con sus respectivas inscripciones. El día 26 la iglesia adelantó el coro para iniciar a tiempo la función solemne a la que acudió la elite. El tesorero de la catedral, Manuel de la Bárcena, pronunció un interesante sermón, un discurso "sólido, enérgico y juicioso" a través del cual la iglesia dejó escuchar su voz: hizo ver a los asistentes "con toda claridad las utilidades comunes que les resultan a los pueblos de obedecer a una sola cabeza, por las ventajas positivas que tiene este gobierno, y por las funestas consecuencias que trae consigo la anarquía". ${ }^{25}$

Al término de las celebraciones, y de común acuerdo con el cabildo civil, el cabildo catedralicio acordó realizar un novenario de misas en el Santuario de Guadalupe, con el fin de implorar a la virgen del Tepeyac su intercesión en favor de la integridad de la religión católica, por la felicidad de las armas españolas y la "aniquilación de los ejércitos que siguen las banderas del pérfido Bonaparte”. Las misas iniciaron el día 5 de septiembre de 1808 por ambos cabildos y le siguieron las comunidades y el clero para terminar el cabildo eclesiástico con la última ceremonia. En ésta, hubo una procesión con todas las corporaciones y comunidades de la iglesia catedral, que cantaron la Letanía de los Santos; y finalizó con una prédica a cargo del Dr. José Díaz de Ortega, canónigo lectoral, con la que se buscaba exhortar a la feligresía a no cesar en sus oraciones. ${ }^{26}$ Misas, sermones y tañidos eclesiásticos se sumaron al espacio sonoro de la fiesta regia para patentizar la presencia de la Iglesia michoacana, a cuya cabeza se encontraba un cabildo catedralicio en ese momento en sede vacante.

Los tañidos de las campanas eran parte importantísima del paisaje sonoro de las ciudades y pueblos novohispanos. ${ }^{27} \mathrm{Su}$ sonido marcaba el tiempo coti-

25 Relación descriptiva (1808, pp. 5-6). El sermón de Manuel de la Bárcena, Sermón que en la jura, 1808 es analizado en Landavazo (2001, pp. 88-91). Sobre De la Bárcena consúltese Ávila (2003, pp. 5-41) y Pérez Vejo (2014, pp. 1583-1650).

26 Relación descriptiva (1808, p. 12).

27 La importancia de las campanas y sus tañidos en la vida religiosa y pública del México colonial e independiente, no exenta de conflictos, se analiza en Staples (1977, pp. 177 - 
diano y festivo de los habitantes. Los códigos emanados de las campanas grandes o pequeñas instaladas en torres, campanarios, espacios conventuales, de las órdenes regulares, o bien de las catedrales, regulaban las prácticas diurnas y nocturnas de los novohispanos. Las campanas congregaban al pueblo, anunciaban las buenas o malas nuevas, servían para alejar tempestades, para calmar epidemias y sequías, y además para exorcizar espacios. Dentro de los programas emblemáticos barrocos la campana constituía la voz de los apóstoles, pues de la misma manera "su pregón alcanza a toda la tierra y su lenguaje hasta los límites del orbe”, por tanto había que elevarla en torres y estructuras que lanzaran sus ondas sonoras a distancias geográficas amplias: "Cominus et eminus (de cerca y de lejos), la fama de la virtud resuena cerca y lejos con el eco mismo de la gloria". ${ }^{28}$

En la ciudad de Valladolid estaban bien establecidos los tiempos y la cantidad de repiques que deberían efectuarse para cada evento: para el anuncio de exequias, por ejemplo, el pregón se acompañaba de la vacante, que constaba de 100 campanadas dobles y pausadas en la catedral para el caso de los obispos, y 200 si se trataba de la muerte del rey. ${ }^{29}$ Las campanadas concluían ya entrada la tarde para dar lugar a una veintena de dobles que se intercalaban con disparos de artillería. El toque de dobles en la ciudad conllevaba un orden, iniciaba la catedral, y era seguida por las distintas iglesias, para lo que el cabildo civil notificaba anticipadamente a priores y representantes de los conventos, del Colegio de la Compañía y del Hospital Real su obligada participación en los

193). Turrent (2008, pp. 28-49) y Carbajal López (2013, pp. 9-26).

28 Picinelli (2006, pp. 147-159).

29 El toque de campanas marcaba además la preeminencia y jerarquías sociales. Así, por ejemplo, "en época de epidemias, para la buena muerte y auxilio de los agonizantes, las campanas de la catedral llamaban a la oración: con cualquier campana grande para el señor prelado y asimismo con los grandes señores capitulares, aunque con la misma campana... y que asimismo se toque para las demás personas, siete golpes por los señores sacerdotes, por varones seis y por mujeres cinco". En Valladolid, el toque de campanas estaba sujeto a las disposiciones del Tercer Concilio Mexicano. Sigaut (coord.) (1991, pp. 41-42). 
solemnes actos, como se hizo para los pregones que anunciaron la muerte de Luis I. ${ }^{30}$

La campana mayor de la catedral tenía un alcance en sus ondas sonoras que llegaba hasta las lomas del norte de la ciudad y pueblos circunvecinos, localizados a una distancia aproximada de 15 kilómetros ${ }^{31}$, por tanto su mensaje sonoro resultaba bastante efectivo. Y como ocurría en otras ciudades novohispanas como Puebla y la ciudad de México, en Valladolid el oficio de campanero otorgaba a quien lo desempeñaba una condición especial, principalmente en ocasión de fiesta, por lo que no resultaba extraño que se aprovechara la saturación del ciclo festivo en la catedral para hacer llegar por parte de los campaneros, sendos oficios solicitando incrementos en sus sueldos. ${ }^{32}$

30 AHMM, Libros manuscritos, no. 3, 1569-1755, f. 160; AHCM Actas de Cabildo, libro no. 36, fs. 195-196. El ritual de reales exequias seguido por la catedral de Valladolid se sujetaba al de la catedral de la ciudad de México, que fue junto con la de Puebla el modelo durante toda la época virreinal. Véase sobre esto Gómez (s/f).

31 Sobre los códigos musicales de las campanas y el alcance geográfico de las ondas sonoras al interior y exterior de conventos, capillas y catedrales, véase el trabajo de Loreto López (2014, pp. 75-96). En el caso del alcance de onda de la campana mayor de la catedral, nuestras deducciones se deben a las pláticas con el campanero mayor de la catedral en el año 2004, y con personas oriundas de los pueblos de Tarímbaro y Copándaro, Michoacán, que coinciden en afirmar que la sonoridad de la campana mayor recorría el lomerío del norte de la ciudad sin menoscabo. Cabe también señalar que las discusiones al interior del Cabildo Catedral de Valladolid sobre quién debería fabricar la campana mayor de la Santa iglesia fueron álgidas unos meses antes de que quedara formalmente inaugurado el edificio más importante de la ciudad. Las actas de Cabildo dan cuenta de que el trabajo de la campana y las esquilas quedó en manos de los maestros Joseph de Medina y Manuel Calvillo Chavarría, AHCM, Libro de actas de cabildo núm. 20, sesión del 4 de diciembre de 1744, ff. 68v, 69.

32 Tal era el caso de doña Brígida Ybar, campanera de la Iglesia Catedral, quien en septiembre de 1788, envió solicitud de incremento en su sueldo, debido a "haberse aumentado el número de funciones", y con ello el gasto en los mozos auxiliares para el repique de campanas, lo cual de inmediato se turnó al tesorero de la catedral para que se procediera a su aprobación. AHCM, Actas de Cabildo, libro núm. 36, cabildo de 13 de septiembre de 1788 , f. 109 . Sobre el significado de las campanas en la sociedad y la cultura novohispana pueden revisarse: Reyes Acevedo (2007, pp. 59-72), Ruiz Caballero (2009, pp. 103-129); Salas Cassy (2009, pp. 193-204), Camacho, Díaz Cayeros y 
Los repiques, redobles y acompañamiento de esquilas daban forma al lenguaje de las fiestas regias, como se observa de igual forma en los natalicios de príncipes que también se festejaron en las ciudades novohispanas. Tan pronto como se sabía del embarazo de reinas y princesas no faltaban las misas de acción de gracias, mientras que las de rogativa se llevaban a cabo cuando el parto se acercaba. Llegado el nacimiento, las noticias se hacían extensivas a todos los rincones del imperio español, a la vez que se invitaba a las instituciones políticas y eclesiásticas a fin de que guardasen los honores que tal acontecimiento demandaba. De esta manera, y después de haberse hecho público el anuncio del nuevo miembro de la familia real, se preparaba la ceremonia religiosa que constituía el evento esencial; sin embargo, un lugar especial lo constituían los repiques al medio día incluyendo el toque de esquilas, los que, iniciados por la catedral, eran acompañados por el resto de las iglesias de los conventos y colegios. ${ }^{33}$

Los desposorios reales, por otro lado, parecían representar una ocasión particularmente festiva, quizá por el carácter promisorio que suele tener todo enlace matrimonial. Por ello su celebración tenía un carácter más popular, incluso que la de las propias juras. De la misma forma que estas últimas, la boda de un rey era anunciada "en altas e inteligibles voces" al son de trompeta, tambor y chirimías, y de igual manera se preparaba la ceremonia religiosa en la catedral vallisoletana donde el acontecimiento se anunciaba con tres días de repique, continuados por todos los conventos y colegios de la ciudad. El sonido de las campanas se acompañaba con luces, fuegos de artificio y bombas,

Gutiérrez (2009, pp. 205-220); Galí Boadella (2009, pp. 221-235). Respecto a la relación del paisaje sonoro con el entramado urbano en las ciudades novohispanas véase el trabajo de Loreto López (2017, pp. 113-152).

33 AHCM, Actas de Cabildo, libro No. 32, fs. 357-357v; AHCM, Actas de Cabildo, libro no. 36, fs. 107-108; AHMM, Actas de cabildo y reales cédulas, 1775-1776 (80) libro no. 42, f. 24v; AHMM, Actas de Cabildo, libro no. 43, 1776-1779, fs. 104-105; AHCM, Actas de Cabildo, libro no. 33, fs. 282-282v. 
mientras que los vecinos eran convidados a participar a través de la iluminación de sus puertas y ventanas con cazuelejas y hachones. ${ }^{34}$

También hubo repiques en la catedral, los conventos, colegio y Hospital Real, con los que dieron inicio los festejos por las campañas militares de Felipe V, con motivo de la Guerra de Sucesión española. Después de la iluminación de la ciudad, de las celebraciones callejeras y de los carros alegóricos, los festejos concluyeron con una celebración litúrgica que tuvo lugar en el convento de San Francisco. La ceremonia reunió al cabildo catedral, a los miembros del ayuntamiento y a los prelados de las órdenes regulares establecidas en la ciudad, quienes participaron en una procesión solemne por el claustro del convento franciscano llevando delante al santo sacramento y depositándolo finalmente en el altar mayor para dar inicio a la misa cantada, en la cual destacó el sermón alusivo a las glorias militares del monarca. ${ }^{35}$

Es de destacar que en Valladolid no hubo mayores repercusiones del debate, que sí se produjo en otras ciudades del virreinato en la segunda mitad del siglo XVIII, sobre la cantidad de días festivos y la participación de las corporaciones civiles y eclesiásticas. Aunque se conocieron los edictos sobre el uso de campanas que emitieron los arzobispos Francisco Antonio de Lorenzana en 1766 y Alonso Núñez de Haro en 1791, la capital michoacana continuó dando rienda suelta a los badajos, principalmente en ocasión de fiesta regia. Es ya bien entrado el siglo XIX que se observan intentos de reglamentar los toques, de insertar en los bandos de policía y buen gobierno las prohibiciones necesarias para evitar que los dobles y repiques se vuelven motivo de molestia para los habitantes de la urbe. ${ }^{36}$

34 AHMM, Libros manuscritos, no. 6, 1555-1759, fs. 145-149v; Real cédula sobre que se publique el matrimonio del rey Fernando con doña Isabel de Farnesio, AHMM, I/5, caja 56, exp. 21, 1715. No fue posible revisar la reciente obra de Vázquez Mantecón (2017), que hubiese sido muy útil seguramente para adentrarse en los significados y simbolismos de la pirotecnia.

35 AHMM, Gobierno, I.2, caja 10, exp. 8, 1711.

36 Sobre los debates en torno al uso y abuso de las campanas véase Dávalos (2001, pp. 181-198). 
RUIDOS POPULARES 37

El entorno sonoro y los aparatos visuales integrados al guión festivo de las juras reales formaban parte sustancial de un mecanismo político de legitimidad monárquica. Ambos instrumentos didácticos crearon una cultura auditiva y visual que invitaba a la participación social, transmitiendo un discurso codificado que pronto fue apropiado por los novohispanos. Desde luego que las ceremonias regias eran también un discurso del orden social y del modelo de sociedad dominante, que podía ser leído a partir de las nociones de jerarquía y precedencia expresadas en el lugar que nobles y plebeyos, autoridades y súbditos, ocupaban en las procesiones, en las funciones religiosas y en las sesiones solemnes en que se formulaba el juramento. ${ }^{38}$ Pero también lo es que los sectores populares tenían capacidad de re-significar la realidad y actuar con cierta autonomía, por lo menos de afirmar su presencia.

Evidentemente las elites ejercían un control sobre las celebraciones y se afanaban por tanto de dirigir la participación popular y considerarla como expresión de la extensa fidelidad que suscitaba la persona del rey y su familia. Sin embargo, difícilmente el paisaje festivo estaba completo sin la presencia activa de los indios: fuese "vestidos a la española" o bien ataviados a la usanza chichimeca para involucrarse en los escenarios festivos a partir de alguna danza, lo cierto es que sus contingentes fueron parte esencial del orden expresado en las ceremonias. A lo largo del siglo XVIII, además, se llegaron a integrar a la labor de los pregoneros autoridades representativas de los pueblos y barrios indios de la ciudad, acompañados de sus instrumentos musicales -tambores, tamboriles y trompetas- que complementaban los pregones. Tal y como ocurrió con los anuncios del fallecimiento de Carlos III hechos a fines de marzo de 1789

37 Por "ruidos populares" queremos referirnos a la dimensión popular del entorno sonoro de las fiestas regias, es decir, los sonidos producidos por sectores no de élite como pueblos de indios y gremios, que se integraban a dicho entorno.

38 Landavazo (2001, p. 105). 
y de la posterior celebración de las honras fúnebres, realizadas los días 2 y 3 de septiembre del mismo año. ${ }^{39}$

En ocasión del enlace matrimonial del príncipe de Asturias y María Luisa de Parma celebrado el 4 de septiembre de 1765, el cabildo municipal, en sus sesiones de 15 y 21 de abril de 1766, decidió convocar a los habitantes de la ciudad a las demostraciones a que estaban obligados por real cédula, que habrían de celebrarse el 4 de mayo de ese año. Para ello se publicó un bando que ordenaba entapizar e iluminar las iglesias, organizar fuegos artificiales y llevar a cabo una procesión hacia la catedral, en donde tendrían lugar la misa solemne y el sermón, encabezados por el cabildo y a los que se unirían los vecinos principales y los antiguos alcaldes ordinarios. Se sumarían también los indígenas, perfectamente vestidos a la española: el gobernador de los indios de la ciudad, los alcaldes de los barrios y los oficiales de los pueblos de Santa María y Jesús del Monte, quienes debían portar traje y sombrero y encima su tilma, sobre la cual debían caer los mechones de pelo conocidos como balcarrias o balcarrotas. ${ }^{40}$

Los festejos que rendían honores a las victorias militares del monarca español se convirtieron en verdaderos eventos populares, en los que la participación de otros grupos sociales parece menos dirigida, más espontánea, más ruidosa. El 14 de agosto de 1711, sea por caso, se iniciaron en Valladolid los repiques en la catedral, los conventos, colegio y hospital real, una vez difundidos entre los súbditos a través de los pregones los acontecimientos ocurridos durante las campañas militares de Felipe V con motivo de la Guerra de Sucesión española, que se habían hecho de conocimiento previamente a los ayuntamientos americanos. Las puertas y ventanas de los vallisoletanos se iluminaron entonces con hachones y en la plaza pública se hicieron estallar "cohetes, bombas, castillos, toros armados, ruedas y montantes", costeados por algunos miembros del ayuntamiento y por el gremio de plateros de la ciudad. ${ }^{41}$

39 Sesiones de Cabildo del 29 de marzo y 29 de agosto de 1789, AHMM, Actas de Cabildo, Libro no. 63, 1788-1789, fs. 30-31v y 44-45.

40 Sesiones de Cabildo del 15 y 21 de abril de 1766, AHMM, Actas de cabildo, Libro no. 28 , fs. $73-75 \mathrm{v}$.

41 AHMM, Gobierno, I.2, caja 10, exp. 8, 1711. 
Las celebraciones callejeras dieron inicio el día 15 a las cuatro de la tarde, cuando el maestro zapatero Luis Rodríguez, "habiendo juntado todos los de su arte, con una máscara, a lo burlesco, anduvieron por toda la ciudad con grande regocijo y demostraciones de alegría”. Al día siguiente se prepararon el gobernador, alcaldes y oficiales de república de la ciudad, sus pueblos y barrios, y efectuaron "la entrada de Moctezuma, con unos indios de paz y otros de guerra, con grande alegría, manifestando sumo gozo en la celebración del festejo". Por su parte, el maestro de los canteros de la catedral de Valladolid y los miembros de su gremio llevaron a cabo una encamisada con luminarias, loas y festejos que duró hasta las ocho de la noche, y el día 17 decidieron representar "la entrada de Cortés" y "el salto de Alvarado con Moctezuma y la Maliche". ${ }^{42}$

La presencia india se complementaba en las ciudades con la participación de los gremios, los cuales se apropiaban de las calles durante los festejos; representantes de estas corporaciones tenían incluso cabida en sesiones de cabildo abierto, para definir su participación durante la fiesta regia. ${ }^{43}$ Así, entre los sonidos populares destacaban los producidos por los oficios. En la ya referida celebración por la Guerra de Sucesión, la encamisada organizada por los tenderos se hizo a caballo "con luces en las manos" y su mojiganga recorrió la ciudad al son de chirimías, trompetas y tambores. Los carpinteros realizaron por su parte una marcha encabezada por un menor montado a caballo, que representaba a Felipe V. Los barberos, herreros, doradores y aguadores llevaron a cabo otra marcha con dos carros alegóricos, una detrás y otro al frente,

42 AHMM, Gobierno, I.2, caja 10, exp. 8, 1711; Martínez Villa (2010, pp. 113-114).

43 No podríamos reflejar cabalmente la vida gremial, dice Antonio Rumeu, si no aludiésemos a la participación de los oficios en las festividades públicas, pues los artesanos eran el elemento obligado en las fiestas religiosas y profanas, “con su carácter juvenil, ingenuo y su espíritu rumboso”. Rumeu de Armas (1944, p. 196). Sobre los gremios y su presencia en las fiestas religiosas y civiles en Nueva España, véase Carrera Stampa (1954, pp. 95-107). La participación de los gremios vallisoletanos en las fiestas regias se aborda en Martínez Villa (2010, pp. 35-37, 89-91 y 113-115). 
acompañado de alabarderos, pajes y lacayos, que desembocó en las casas reales en donde se escucharon tiros de salva, bombas y cohetes. ${ }^{44}$

Las celebraciones por los desposorios regios permitían también una mayor participación de los gremios de la ciudad. Así ocurrió en los festejos por el matrimonio del príncipe Luis Fernando I y Luisa Isabela de Orleáns en 1722, para cuya organización el propio ayuntamiento abrió a sus representantes la sesión del cabildo del 9 de julio, en la cual se acordaron las actividades que llevarían a cabo: los plateros organizarían «una noche de fuegos»; los carpinteros, carroceros y doradores el "festejo de encamisada y paseo otro día"; los sastres, un carro y paseo; los canteros, una mascarada "y lo más que pudiesen"; el maestro de capilla con los músicos, un carro de música y loas por dos noches; los barreros, una encamisada y loa una noche; los herreros, una mojiganga con su loa; los obrajeros, tintoreros y sombrereros, una encamisada con dos loas en una noche; los zapateros, encamisada, loa y paseo; el gremio de los músicos de arpa tocarían durante todo el festejo, además de organizar una mojiganga; los cereros, dulceros, aguadores y coheteros organizarían el festejo de su elección; y finalmente, las repúblicas de indios llevarían a cabo "el festejo de Montezuma", 45 o sea, la recreación de episodios de la conquista.

En los festejos ya referidos por la boda de quien sería después Carlos IV, en mayo de 1766, lo gremios de la ciudad fueron igualmente convocados por el cabildo a la sesión del 22 de abril, con quienes se acordó la siguiente participación: los canteros, quebraderos y albañiles harían una mascarada por la tarde del lunes cinco de mayo; los zapateros, curtidores y guarnicioneros harían otra el martes, el miércoles, burreros, carreteros y herreros echarían "un carro a la burlesca"; el jueves sería el turno de los plateros, para hacer "la

44 AHMM, Gobierno, I.2, caja 10, exp. 8, 1711.

45 Sesión de Cabildo del 9 de julio de 1722, AHMM, Libros manuscritos, no. 15, 17191734, fs. 210-211. Este documento fue dado a conocer por Guzmán Pérez (1991, pp. 155-157). Sobre las encamisadas o mojigangas, que eran desfiles de caballeros vestidos con camisas blancas o disfrazados de personajes históricos o alegóricos, véase Weckmann (1996, p. 134) y Leonard (1990, pp. 174-190). Sobre la participación popular en las fiestas regias en Valladolid, lo que llama el complemento lúdico, véase Martínez Villa (2010, pp. 109-115). 
demostración que les sea posible"; el viernes tocó a barberos, cereros, veleros y panaderos una máscara "a la gitana"; el sábado, obrajeros, coheteros y tocineros harían otra máscara; el domingo estaba reservado para que saliese el carro triunfal, a cargo de sastres y cigarreros. Y el siguiente domingo volvería a salir el mismo carro, pero ahora con los pintores, carroceros y doradores, quienes le harían añadidos a gusto, "a lo serio o ya de máscara". ${ }^{46}$

La presencia popular y sus ruidos en los festejos regios no se reducían a los indios y a los gremios, aunque estos desde luego destacaban por su importancia social. Casi todas las crónicas y testimonios dan cuenta de la festiva participación de muchos habitantes de la ciudad y de sus alrededores, y del bullicio general que se producía en consecuencia por los murmullos, los gritos, las correrías, las risas, las aclamaciones, los fuegos artificiales, las salvas, los toros y la música. En la jura de Fernando VI, los músicos tocaron los tres días por la mañana y por las tardes se dispararon cohetes y se quemaron bombas; las actividades duraban hasta la medianoche y una multitud de curiosos de las inmediaciones acudieron "ávidos de divertirse". Durante la proclamación de Carlos IV en 1791, por otra parte, las orquestas que tocaron durante los tres días en las casas del ayuntamiento y del Alférez "aumentaron considerablemente el regocijo público sin que hubiera la menor desgracia porque el inmenso concurso que había de plebe parecía que estaba absorbido de ideas de honor y únicamente dedicado a celebrar a su majestad". ${ }^{47}$

Las circunstancias tan especiales que vivía la monarquía española en 1808 abrieron un espacio social para la participación popular, que se observó claramente durante los tres días que duró la jura de Fernando VII. La crónica pone de manifiesto la enorme inquietud y expectación sociales en vísperas de la ceremonia: la alegría en el semblante de la gente junto a los murmullos que resonaban en calles y plazas; las corporaciones que se estimulaban unas a otras y la agitación al "explicar” el corazón "con mil invenciones festivas”; los golpes

46 Sesión de Cabildo del 22 de abril de 1766, AHMM, Actas de cabildo, Libro no. 28, fs. $75 \mathrm{v}-76$.

47 Rivera Cambas (1883, p. 449). AHMM, Gobierno, caja 48, exp. 10, año 1791, 8 fs, Valladolid, 12 de mayo de 1791. 
de música en los tablados próximos a la Intendencia y alférez real que eran seguidos por el pueblo que discurría por los lugares públicos con júbilo y que se congregó en la plaza cuando se encendieron los fuegos artificiales. El 25 por la tarde, día central de la ceremonia, el tiempo ordinario se suspendió para dar paso al tiempo de la fiesta: "toda otra ocupación se olvida y desatiende, el tráfico aunque tan necesario del comercio se suspende por una orden expresa, calla el afán ruidoso de los artes y sólo se percibe el susurro del gozo y la sonora voz de las campanas y los truenos". ${ }^{48}$

De pronto, la multitud ya agitada precipitó las cosas: rebosante en la anchurosa plaza, nos describe el narrador, la turba se derramó con igualdad por las entradas todas de las calles, y con su violencia logró que el alférez ordenase el paseo antes de la hora acostumbrada. La nobleza, lujosamente ataviada y con orden en la procesión, no logró sin embargo avanzar por la presión de la plebe "que se equilibra a todos lados"; los caballos nadaban sobre "las olas de hombres" y los caballeros navegaban con fatiga un trecho que en situación normal habrían hecho con facilidad en minutos. Al llegar finalmente la comitiva al tablado del intendente, el pueblo impaciente, al ver a los reyes de armas, "sin esperar la voz del Alférez (porque quería cada uno proclamarlo el primero)" gritó vivas a Fernando. La voz del pueblo "rimbomba” se repitió, y ahogó los vivas del alférez que se esforzó en vano. Cuando el retrato del monarca se descubrió sobre el tablado, retumbó el estallido de los truenos, se deshicieron en aclamación las campanas, llovieron las monedas de todas las clases sobre la multitud y la confusión resultante pintó "con sus propios colores el entusiasmo y alborozo".49

Esa turbamulta impaciente y violenta volvió a pintar "con sus propios colores" su entusiasmo en casa del alférez, de donde se habían retirado del tablado los retratos del monarca por causa de la lluvia que había caído por la tarde. Mas en la noche, una vez que escampó, el pueblo "atropado" se presentó enfrente del dosel en actitud exigente; el alférez ordenó entonces a los músicos salieran a tocar, creyendo que era lo que pedían, a lo que siguió un grito

48 Relación descriptiva (1808, pp. 2-3).

49 Relación descriptiva (1808, pp. 3-4). 
uniforme: "queremos a Fernando", es decir, que se colocasen de nuevo los retratos del rey. Como se demoraron en hacerlo en el afán de arreglar el sitio con decoro, la multitud exacerbada clamó -siempre según la crónica que hemos beneficiado- que el monarca no precisaba de adornos; cuando al fin apareció el retrato, se produjo la apoteosis: numerosos vivas y aclamaciones de gozo, paseos por las calles con la música que había cedido el alférez, repiques de campanas de todas las iglesias. Según el relator, la turba, con sus "demostraciones singulares" había logrado repetir "una jura nocturna" y con ello que Fernando adquiriese "el renombre envidiable de El Príncipe querido". ${ }^{50}$

\section{CONCLUSIONES}

Parece ser claro que las ceremonias regias, tal y como hemos visto en el caso de Valladolid de Michoacán durante el reinado de los Borbones, se complementaban con una diversidad de elementos lúdicos y sonoros que no sólo provocaban un impacto visual y auditivo muy importante, sino servían al propósito de socialización política, de manera satírica o seria, instruyendo, divirtiendo y fijando en el imaginario político y social la figura de un monarca legítimo y majestuoso. Esta diversidad de expresiones lúdicas y sonoras marcaba paso a paso el ritmo de la fiesta, anunciando el inicio de las ceremonias, advirtiendo sus momentos clave y señalando el momento preciso en que llegaban a su fin.

Los gritos de los pregoneros, el impresionante llamado de los reyes de armas y el retumbar del paseo del Real Pendón; la música de los órganos de la catedral, los cantos a media voz de los fieles durante las misas y procesiones, el repicar de las campanas o la solemne lectura del sermón; las mascaradas y los carros alegóricos, el bullicio de las multitudes, lo mismo que los repiques, los cohetes y demás fuegos de artificio: materiales todos ellos que fueron conformando una cultura sonora entre una sociedad mayoritariamente analfabeta, puesta al servicio de las fiestas regias.

50 Relación descriptiva (1808, p. 6). 
Las sonoridades de las fiestas regias respondían a lógicas distintas. Las de índole política y eclesiástica se constituyeron en instrumentos de las jerarquías políticas y sociales como advertimos al inicio de este texto: los pregones eran el vehículo de las disposiciones de la autoridad a las que había que atender; el llamado de los reyes de armas señalaban el momento preciso de la solemnidad del juramento a la vez que la indicación de guardar obediente y respetuoso silencio; el sonido de las monedas arrojadas a la multitud hacía ostensible quién podía dar y quién podía tan sólo recibir; la música sacra recordaba el lazo que unía el poder real con el divino cantado en la letra del Te Deum Laudamus; el sermón era un discurso del orden que establecía deberes cristianos y obligaciones políticas, con la solemnidad y el aparato que solamente el púlpito podía dar. Sonidos del poder que pautaban los comportamientos deseables.

Pero el entorno sonoro de las ceremonias se nutría también de los ruidos populares: mojigangas, mascaradas, bullicio, gritos, jaloneos, exigencias, cantos, bailes, rumores, complementado a su vez con una exuberante arquitectura efímera que deleitaba la mirada a la par que sumaba significados al paisaje sonoro de la ciudad en fiesta. Un repertorio que se salía en ocasiones del libreto que las elites de la ciudad se afanaban en imponer. La jura de Fernando VII lo ejemplifica bien: aunque el autor de la Relación descriptiva, como hemos visto, quiso presentar como muestras de la extrema fidelidad vallisoletana la impaciente exigencia de la multitud para iniciar de una buena vez el paseo del Pendón, o para que se exhibiese el retrato del monarca, lo cierto es que la imposición popular del ritmo de la celebración en ambos episodios se acercó a formas de transgresión punibles en circunstancias distintas. El entorno sonoro de la fiesta podía ser también espacio para la expresión popular más o menos autónoma.

El espacio festivo de las ceremonias regias, delimitado a partir del paseo del real pendón, estaba marcado por los referentes espaciales del poder político más importantes en ese momento. Lo muestra con claridad el hecho de que los tablados fueran levantados frente a las casas reales, el palacio episcopal y, en fechas más tardías, la Intendencia. Podríamos decir, en tal virtud, que las fiestas regias y el heterogéneo entorno sonoro por ellas creado contribuyeron a la construcción simbólica de la ciudad. Una construcción modelada desde luego 
por los proyectos políticos de la autoridad civil y por el papel rector que desempeñó el cabildo eclesiástico a lo largo del periodo virreinal, pero también, como insinúan los ruidos populares, por la presencia heterogénea y activa de los grupos sociales vallisoletanos.

\section{FUENTES}

- Archivo Histórico de la Catedral de Morelia (AHCM).

- Archivo Histórico Municipal de Morelia (AHMM).

- Gazeta de México.

- Relación descriptiva de la función de jura del señor Don Fernando VII, celebrada en la Ciudad de Valladolid de Michoacán los días 24, 25 y 26 de agosto de 1808, México, En la calle de Santo Domingo, 1808.

- Rigor y Piedad de el rayo de la muerte, en la pérdida y restauración de las dos vidas, política y natural del augustísimo señor Don Luis Primero..., que en las funerales, sumptuosas exequias... celebró la... Santa Iglesia Catedral de Valladolid de Michoacán... el día cinco de julio del año de 1725, predicó D. Luis Calvillo,... con licencia en México, por los Herederos de la viuda de Miguel de Rivera (en el Empedradillo), 1727.

- Sermón que en la jura del señor Don Fernando VII (que Dios guarde) dijo en la catedral

- de Valladolid de Michoacán el Dr. D. Manuel de la Bárcena, Tesorero de la misma Iglesia y Rector del Colegio Seminario, el día 26 de agosto de 1808, México, Imprenta de Arizpe, 1808.

\section{BIBLIOGRAFÍA}

- Alberro, S. (2012). Reyes y monarquía en las fiestas virreinales de la Nueva España y del Perú. En O. Mazín (Ed.). Las representaciones del poder en las sociedades hispánicas (pp. 275-300). México: El Colegio de México.

- Ávila, A. (2003). El cristiano constitucional libertad, derecho y naturaleza en la retórica de Manuel de la Bárcena. Estudios de Historia Moderna y Contemporánea, 25, enero-junio, pp. 5-41.

- Ávila, A. y Pérez Herrero, P. (coords.) (2008). Las experiencias de 1808 en Iberoamérica. México: Universidad Nacional Autónoma de México, Instituto de 
Investigaciones Históricas/Universidad de Alcalá, Instituto de Estudios Latinoamericanos.

- Breña, R. (editor) (2010). En el umbral de las revoluciones hispánicas: el bienio 1808- 1810. México-Madrid: El Colegio de México/Centro de Estudios Políticos y Constitucionales.

- Calvo, Th. (2003). Conocer a su rey y encarnar el poder: la difusión de la figura real en América hispánica (siglos XVI-XVIII). Historias, 56, México, septiembrediciembre, pp. 23-41.

- Calvo, Th. (2005). La jura de Fernando VI en Guadalajara (1747): de la religión real a la festividad, Takwá, 8, pp. 67-92.

- Calvo, Th. (2011). Proclamations royales et Indiens au XVIIIe siècle: enjeux politiques et sociaux. Anuario de Estudios Americanos, 68, 1, enero-junio, pp. 73-103.

- Camacho, A., Díaz Cayeros, P., y Gutiérrez, D. (2009). Llamado a sermón. Sobre el reglamento de campanas de la Catedral de Guadalajara. En IV Coloquio Musicat. Harmonia Mundi: Los instrumentos sonoros en Iberoamérica, siglos XVI al XIX. (pp. 205-220). México: Universidad Nacional Autónoma de México.

- Carbajal López, D. (2013). Jerarquías, jurisdicciones y sensibilidades: aspectos de la reforma de las campanas en Nueva España, 1700-1808. Secuencia. Revista de Historia y Ciencias Sociales, 86, mayo-agosto, pp. 9-26.

- Carrera Stampa, M. (1954). Los gremios mexicanos. La organización gremial en Nueva España, 1521-1861. Prólogo de Rafael Altamira. México: EDIAPSA.

- Chiva Beltrán, J. (2012). El triunfo del virrey, Glorias novohispanas: origen, apogeo y ocaso de la entrada virreinal. Castelló: Universitat Jaume I.

- Chust, M. (coord.). (2007). 1808. La eclosión juntera en el mundo hispano. México: El Colegio de México/Fondo de Cultura Económica.

- Darnton, R. (1987). La gran matanza de gatos y otros episodios en la historia de la cultura francesa. México: Fondo de Cultura Económica.

- Dávalos, M. (2001). El lenguaje de las campanas. Revista de Historia Social y de las Mentalidades, 5, invierno, pp. 181-198.

- Enríquez, L. (Ed.) (2009). IV Coloquio Musicat. Harmonia Mundi: Los instrumentos sonoros en Iberoamérica, siglos XVI al XIX. México: Universidad Nacional Autónoma de México. 
- Escobar Olmedo, A. (1988). Las fiestas en Pátzcuaro de 1701 por la aclamación del rey Felipe V". Tzintzun, Revista de Estudios Históricos, 9, enero-diciembre, pp. 139-166.

- Galí Boadella, M. (2009). Las campanas en una ciudad episcopal novohispana en vísperas de la Independencia. IV Coloquio Musicat. Harmonia Mundi: Los instrumentos sonoros en Iberoamérica, siglos XVI al XIX. (pp. 221-235). México: Universidad Nacional Autónoma de México.

- Gómez, V. (s.f.). El costumbrero de la catedral de México 1819. México: Diócesis de San Cristóbal de las Casas Chiapas, A.R./Sociedad Mexicana de Historia Eclesiástica, A.C.

- Gonzalbo Aizpuru, P. (ed.). (2014). Espacios en la historia. Invención y transformación de los espacios sociales. México: El Colegio de México.

- Guzmán Pérez, M. (1991). Los gremios de la ciudad de Valladolid de Michoacán en 1722. Tzintzun. Revista de estudios históricos, 13, enero-junio, pp. 155-157.

- Herrejón Peredo, C. (2003). Del sermón al discurso cívico, México, 1760-1834, México: El Colegio de Michoacán/El Colegio de México.

- Herrera, J. (2006). A las armas corred: un llamado al combate por la libertad hacia el final del virreinato novohispano. Cuadernos del Seminario Nacional de Música en la Nueva España y el México Independiente, 1, diciembre, pp. 24-38.

- Historia Mexicana (2008), 58, 1 (229) julio-septiembre.

- Juárez Nieto, C. (2008). El proceso político de la independencia en Valladolid de Michoacán 1808-1821. Morelia: Universidad Michoacana de San Nicolás de Hidalgo/Instituto Nacional de Antropología e Historia.

- Landavazo, M. A. (2001). La máscara de Fernando VII. Discurso e imaginario monárquicos en una época de crisis. Nueva España, 1808-1822. México: El Colegio de México/Universidad Michoacana de San Nicolás de Hidalgo/El Colegio de Michoacán.

- Leonard, I. A. (1990). La época barroca en el México colonial. México: Fondo de Cultura Económica.

- Loreto López, R. (2017). Los barrocos sonidos del poder. Representaciones, orden y control urbano. Puebla de Los Ángeles, siglos XVII y XVII. En Martínez López Cano, M. P., y Cervantes Bello, F.J. (coord.) (2017). Expresiones y estrategias. La Iglesia en el orden social novohispano (pp. 113-152). México: Universidad Nacional 
Autónoma de México/Instituto de Investigaciones Históricas, Benemérita Universidad Autónoma de Puebla, Instituto de Ciencias Sociales y Humanidades “Alfonso Vélez Pliego.

- Loreto López. R. (2014). Campanas, esquilones y esquilitas. El espacio y el orden de la sonoridad conventual en la Puebla de los Ángeles del siglo XVIII. En Gonzalbo Aizpuru, P. (ed.). Espacios en la historia. Invención y transformación de los espacios sociales (pp. 75-96). México: El Colegio de México.

- Martínez Villa, J. (2010). La fiesta regia en Valladolid de Michoacán. Política, sociedad y cultura en el México borbónico. Morelia: Universidad Michoacana de San Nicolás de Hidalgo.

- Mazín, O. (2006). La música en las catedrales de la Nueva España. La capilla de Valladolid de Michoacán (siglos XVI -XVIII). En Enríquez, L. y Covarrubias, M. (ed.) I Coloquio Musicat. MÚSICA, CATEDRAL Y SOCIEDAD (pp. 205-218). México: Universidad Nacional Autónoma de México.

- Mejía Zavala, E. (2003). Testimonios de la proclamación de Carlos IV en Valladolid de Michoacán en 1791. Tzintzun. Revista de Estudios Históricos, 38, julio-diciembre, pp. 163-224

- Mínguez V. (1995). Los reyes distantes, imágenes del poder en el México virreinal. Castelló: Universitat Jaume I.

- Mínguez, V., Rodríguez Moya, I., González Tornel, P. y Chiva Beltrán, J. (2012). La fiesta barroca. Los virreinatos americanos (1560-1808). Castelló-Las Palmas de Gran Canaria: Universitat Jaume I/Universidad de las Palmas de Gran Canaria.

- Mínguez, V. y Rodríguez Moya, I. (2006). Las ciudades del absolutismo, arte, urbanismo y magnificencia en Europa y América durante los siglos XV-XVIII. Castelló: Universitat Jaume I.

- Pérez Vejo, T. (2014). Manuel de la Bárcena y Arce: una vida entre dos mundos. Historia Mexicana, 63: 4, abril-junio, pp. 1583-1650.

- Picinelli, F. (2006). El mundo simbólico. Los metales, Los instrumentos eclesiásticos, (libros XIII-XIV). Zamora: El Colegio de Michoacán.

- Pulido Echeveste, M. (2014). Las ciudades de Mechuacan: nobleza, memoria y espacio sagrado en la disputa por la capitalidad. Tzintzuntzan, Pátzcuaro, Valladolid. Siglos XVI-XVIII, tesis de doctorado en historia del arte, Facultad de Filosofía 
y Letras, Instituto de Investigaciones Estéticas, Universidad Nacional Autónoma de México.

- Reyes Acevedo, R. Y. (2007). Campanas de la catedral de México (1653-1671): adquisición, uso, conflictos y consagración. En Díaz Cayeros, P. (ed.). II Coloquio Musicat. Lo sonoro en el ritual catedralicio: Iberoamérica, Siglos XVI-XIX (pp. 59-72). Guadalajara: Universidad Nacional Autónoma de México, Universidad de Guadalajara.

- Rivera Cambas, M. (1883). México pintoresco, artístico y monumental: vistas, descripción, anécdotas y episodios de los lugares más notables de la capital y de los estados, aun de las poblaciones cortas, pero de importancia geográfica o histórica. México: Imprenta de la Reforma, tomo tercero.

- Rodríguez Moya I. y Mínguez V. (Dirs.) (2016). Visiones de un Imperio en fiesta. Madrid: Fundación Carlos Amberes.

- Rubial García, A. (2017). Iconos vivientes y sabrosos huesos. El papel de los obispos en la construcción del capital simbólico de la episcópolis de la Nueva España (16101730). En Martínez López Cano, M. P. y Cervantes Bello. F. J. (coord.). Expresiones $y$ estrategias. La Iglesia en el orden social novohispano (pp. 217-266). México: Universidad Nacional Autónoma de México/Instituto de Investigaciones Históricas, Benemérita Universidad Autónoma de Puebla, Instituto de Ciencias Sociales y Humanidades “Alfonso Vélez Pliego”.

- Ruiz Caballero, A. (2009). Campanas y órganos: los artefactos de la discordia en el traslado de la catedral de Tzintzuntzan a Pátzcuaro, siglo XVI. IV Coloquio Musicat. Harmonia Mundi: Los instrumentos sonoros en Iberoamérica, siglos XVI al XIX (pp. 103-129). México: Universidad Nacional Autónoma de México.

- Rumeu de Armas, A. (1944). Historia de la previsión social en España. CofradíasGremios-Hermandades-Montepíos. Madrid: Editorial Revista de Derecho Privado (Serie G. Manuales de derecho, vol. XI).

- Salas Cassy, E. (2009). Las campanas: sus funciones y simbolismo en el ritual fúnebre Catedralicio. IV Coloquio Musicat. Harmonia Mundi: Los instrumentos sonoros en Iberoamérica, siglos XVI al XIX (pp. 193-204). México: Universidad Nacional Autónoma de México.

- Schafer, R. M. (1994). The Soundscape. Our Sonic Environment and the Tuning of the World. Vermont: Destiny. 
- Sigaut, N. Mazín, O., Pérez Martínez, H., Estrada de Gerlero, E. (coord.) (1991). La Catedral de Morelia. Zamora: El Colegio de Michoacán/Gobierno del Estado de Michoacán.

- Staples, A. (1977). El abuso de las campanas en el siglo pasado. Historia Mexicana, XXVII: 2, octubre-diciembre, pp. 177-193.

- Turrent, L. (2008). Música y autoridad. El caso de los toques de campana de la catedral metropolitana, 1791-1804. Istor, 38, otoño, pp. 28-49.

- Varela, J. (1990). La muerte del Rey. El ceremonial funerario de la Monarquía Española (1500-1885). Madrid: Ediciones Turner.

- Vázquez Mantecón, M. C. (2017). Cohetes de regocijo. Una interpretación de la fiesta mexicana. México: Universidad Nacional Autónoma de México, Instituto de Investigaciones Históricas.

- Weckmann, L. (1996). La herencia medieval en México. México: El Colegio de México/Fondo de Cultura Económica. 